\title{
An experiment with PBL in higher education as appraised by the teacher and students*
}

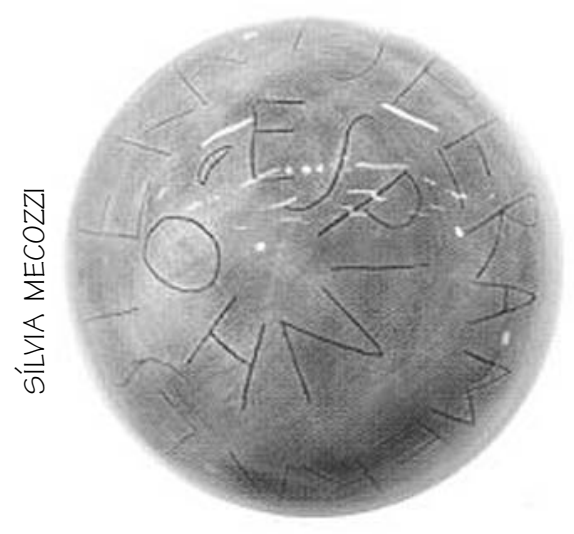

Luis Roberto de Camargo Ribeiro ${ }^{1}$ Maria da Graça Mizukami ${ }^{2}$

RIBEIRO, L. R. C.; MIZUKAMI, M. G. An experiment with PBL in higher education as appraised by the teacher and students. Interface - Comunic., Saúde, Educ., v.9, n.17, p.357-68, mar/ago 2005.

PBL (Problem-based Learning) has gained worldwide acceptance as an effective instructional approach that helps students to acquire knowledge as well as develop desired professional skills and attitudes. Contrary to other conventional methods that use problems after theory has been introduced, PBL uses a problem to initiate, focus and motivate the learning of new concepts. This paper presents and discusses the students' and the teacher's viewpoints on the implementation of PBL in an Administration Theory course of an engineering curriculum at a public university in Brazil. The data were collected by means of unstructured interviews, participant observation and an open-ended questionnaire responded by the students at the end of the course. The results show that despite increasing the workload for the teacher and the students, both evaluated PBL positively because it is more motivating and dynamic.

KEY WORDS: problem-based learning; higher education; teaching methodology.

A Aprendizagem Baseada em Problemas (Problem-based Learning ou PBL) tem sido reconhecida mundialmente como uma abordagem instrucional capaz de promover a aquisição de conhecimentos pelos alunos ao mesmo tempo que os ajuda a desenvolver habilidades e atitudes profissionais desejáveis. Ao contrário de outros métodos convencionais que usam problemas de aplicação depois que a teoria foi apresentada, a PBL utiliza um problema para iniciar, enfocar e motivar a aprendizagem de novos conceitos. Este trabalho apresenta e discute os pontos de vista dos alunos e professor sobre uma implementação da PBL em uma disciplina de Teoria Geral de Administração de um currículo de engenharia de uma universidade pública no Estado de São Paulo, Brasil. Os dados foram coletados mediante entrevistas não estruturadas, observação participante e um questionário respondido pelos alunos ao final do semestre. Os resultados mostram que, apesar de aumentar a carga de trabalho para o professor e os alunos, ambos avaliaram a PBL positivamente por ser mais motivadora e dinâmica.

PALAVRAS-CHAVE: aprendizado baseado em problemas; educação superior; metodologia de ensino.

\footnotetext{
* The authors are grateful to the teacher, who volunteered to take part in this research, and to CAPES, for the financial support.

${ }^{1}$ Professor, Programa de Pós-Graduação em Educação, Centro de Educação e Ciências Humanas, Departamento de Metodologia de Ensino, Universidade Federal de São Carlos, São Carlos, SP. <luisrcr@itelefonica.com.br>

${ }^{2}$ Professora, Centro de Educação e Ciências Humanas, Departamento de Medotologia de Ensino, Universidade Federal de São Carlos. $<$ dmgn@power.ufscar.br>

${ }^{1}$ Rodovia Washington Luís, km 235

São Carlos, SP

13.565-905
} 
RIBEIRO, L. R.; MIZUKAMI, M. G.

\section{Introduction}

Recent studies about the goals of higher education have consistently linked them to the students' future professional careers. For instance, we find in Tynjälä (1999) that higher education should aim at the students' professional training, life-long learning, and preparation for their professional practice and for the professional world in general, which may be accomplished by integrating theory with practice into the curriculum, promoting the students' acquisition of specific and general knowledge, fostering their ability to think analytically and conceptually, encouraging them to develop written and oral communication skills and interpersonal skills, and providing them with opportunities to reflect on, and learn from, practical situations.

In engineering education, these objectives have been supported by surveys about desired professional profiles carried out among academics, prospective employers, and practicing engineers (Ning, 1995). The results of these studies indicate the need for both depth and breadth in engineering education - a curriculum that can promote the acquisition of scientific and technological knowledge, as well as the development of skills and attitudes. However, as the curricula are already overburdened and it is impractical to extend the courses, it is mandatory that these three categories of knowledge, i.e. technical and scientific knowledge, skills and attitudes, are dealt with simultaneously in the curriculum.

There are several educational approaches that aim at providing depth as well as breadth in higher education, such as student-centered education, active learning, case-based learning and inquiry-based learning, to name a few. One such approach is Problem-based Learning (PBL), which seems to encompass many of the characteristics of other alternative approaches and is renowned, according to Savin-Baden (2000), for its capacity to foster knowledge acquisition and the development of professional skills and attitudes, without the need for subjects especially conceived to this end.

Problem-based Learning (PBL)

Contrary to conventional methods that pose application problems after theory has been introduced to the students, PBL is an instructional approach that uses a problem to initiate, focus and motivate learning. Although originally conceived for the teaching of medicine (McMaster University, Canada, mid1960 's), PBL has since expanded to the teaching of other university disciplines, including engineering (Woods, 1996), and to other educational levels. Furthermore, even though it was conceived to be implemented in the whole curriculum, PBL has also been used as a partial method of instruction, such as in one subject within a traditional course (Wilkerson \& Gijselaers, 1996) or even in some parts of a single subject (Stepien \& Gallagher, 1998).

As a result, $\mathrm{PBL}$ implementations may vary according to many factors, including the contexts, disciplines, curricula and institutions where it is used. However, most of the uses of this method are characterized by the following process (Barrows, 2001; Engel, 1998): a) a problem is presented to the students, who, in teams, try to define it and solve it with whatever knowledge they may have; b) by means of discussion they elicit the aspects of the problem they do not understand; c) they prioritize the learning issues and decide how, 
when and by whom they will be investigated, to be later shared with the other team members; d) when they meet again they explore the previous learning issues and integrate the new knowledge into the context of the problem; and e) after having finished working with the problem, they assess the process, themselves and their peers.

It should be remarked that the PBL process does not solely aim at teaching students how to be successful problem solvers. In spite of its name, the development of an effective problem-solving process is just one of the goals of PBL. This method is also intended to assist students in the acquisition of an integrated knowledge base structured around real-life problems and in the development of skills and attitudes, including teamwork and self-directed learning skills, cooperation, ethics and respect for other people's points of view.

Needless to say, the adoption of PBL implies structural and curricular changes in the schools and/or courses. However, these changes alone do not suffice; there is also the need for cultural change, especially regarding the roles played by the main actors: teachers and students. PBL calls for a teacher role different from that found in conventional classrooms, as it demands that teachers act as facilitators, mentors or tutors in the process of knowledge construction carried out by the students instead of just imparting knowledge to them. Although this role may not be entirely unfamiliar to higher education teachers (as many also act as graduate students' advisors), this change may not come about so easily due to diverse internal and external pressures, such as their fear of losing control (as regards content coverage and classroom management) and an increase in their workload.

This change can also be hindered by the students themselves, especially recent school leavers, who - having been through (and thrived in) years of a type of schooling rooted in passive information reception - might expect the same instructional approach from all teachers. On the contrary, the students must play a distinct role in $\mathrm{PBL}$, by taking up responsibility for their own learning so that the educational goals of this instructional method may be attained.

Therefore, it seems that securing the teacher and students' understanding of, and commitment to, PBL is fundamental to the success of an implementation of this method, by granting them the opportunity to voice their opinions and concerns. Based on this assumption, this study seeks to investigate the implementation of PBL in a subject offered at the undergraduate and graduate levels of a public university in Brazil by focusing on how the students and the teacher evaluate this method of instruction as compared to more conventional ones. In so doing, this study also intends to contribute to the literature on PBL given that, according to Savin-Baden (2000), there has been little research to date on the impact of this method on the teachers' and students' lives.

Methodology

This research adopted a qualitative approach as this design is recommended when one wishes to study things in their natural settings, "attempting to make sense of, or interpret, phenomena in terms of the meaning people bring 
to them" (Denzin \& Lincoln, 1994, p.4). It also adopted a collaborative approach inspired by Cole \& Knowles (1993) in that the planning, implementation and, to some extent, data collection and assessment were shared by the researchers and the teacher (a researcher himself in the field of Business Administration).

Based on the aforementioned principles and activities, PBL was implemented simultaneously in two Administration Theory courses (of the undergraduate and graduate industrial engineering curricula at a public university in Brazil in 2002) taught by the same teacher and covering a similar syllabus. The undergraduate class (UG) had 28 students ( $24 \mathrm{M}$ and $4 \mathrm{~F}$, 19-20 years of age) and the graduate class (G) had 23 students ( $17 \mathrm{M}$ and $6 \mathrm{~F}$, 24-50 years of age). The students had one class per week lasting 100 minutes (UG) and 200 minutes (G) during 15 weeks, in which 12 problems were presented (1 per week). The students divided themselves into teams (4-6 students each), in which they took up different roles (leader, spokesperson, scribe, and participating members), rotating every week. (These teams were changed at mid-term to promote exchange of teamwork experiences and more impersonal interactions.)

The PBL cycle began in the second half of each class with the introduction of the problem, followed by group discussion and presentation of a preliminary report containing the team's problem identification, hypotheses, learning issues and teamwork plan for the subsequent week. During this phase the teacher walked around the classroom, assisting in the teamwork and answering pertinent theoretical questions. In the first half of the following class the scribes had to hand in a final report (with the items from the previous preliminary report plus the team's solution to the problem and the theoretical framework used), which was then presented orally by the spokespersons. Each presentation was followed by a short debate between the team, the teacher and other classmates. When all the teams had finished presenting their solutions the teacher commented on them and synthesized the theory prompted by the problem. Afterwards the leaders individually assessed the process, their own performance and that of their team members. The teams also evaluated the educational process (the problem, the presentations, the teacher's synthesis etc.). The students' final grades were composed of marks received for their presentations, the preliminary and final reports, and the selfand peer-evaluations for the 12 problems introduced during the semester.

Research data was collected by means of unstructured interviews with the students and the teacher, participant observation of classes and perusal of artifacts produced by the teacher (problems, performance evaluation forms etc.) and the students (reports, self- and peer-evaluations, posters etc.). In addition, a questionnaire was given to the students at the end of the semester (responded by 26 UG and $21 \mathrm{G}$ students) in which they were asked to evaluate the adopted method of instruction and indicate whether the course goals (knowledge, skills and attitudes) had been achieved.

\section{Results and discussion}

On the whole, most of the UG students (85\%) and nearly all of the G students (91\%) evaluated the instructional method positively, as illustrated by the

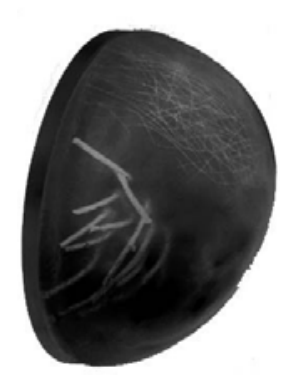


following excerpts: "The instructional method, after it was grasped, worked very well because [...] it favored competencies other than technical ones" (UG04) and "I liked the adopted method very much [...], the class was more dynamic, and it was more easily understood" (G19). This level of student satisfaction is consistent with the literature and has been used, according to Albanese \& Mitchell (1993, p. 63), as a strong argument in favor of PBL, as it may "instill in students a joy of learning that will nurture them so that they become life-long learners". The teacher's general appraisal of the methodology was also positive, because, among other things, it made his classes more dynamic and interesting. His satisfaction also supports the findings of Albanese \& Mitchell's (1993) meta-analysis.

The students' perceptions of the method Besides making the class more pleasurable, both student cohorts credited PBL with the potential to promote self-directed learning: "The advantage is that the students do not get the theory on a platter, and as a result, they have to search for it. Hence, they learn better" (UGO1); more integration between theory and practice and between class work and the students' future professional practice: "By having us do research, as in the real world, we found the knowledge needed for our work and our lives" (G09) and "I personally think [the method] was very good, especially the change of teams [at midterm], which simulated a real-life situation in organizations" (G10); more student involvement: "I liked the method very much because we are continually in touch with the subject matter, and always updating our knowledge" (UG23) and "The method encourages more commitment and responsibility [on the part of the students]" (G07); more integration among the students; multiple visions about the same topic etc. G12's comment sums up these points:

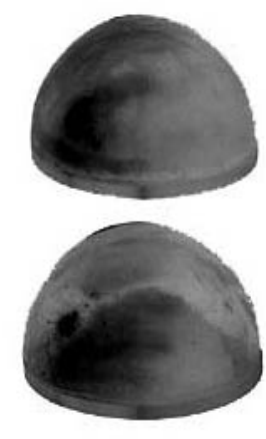

$$
\begin{aligned}
& \text { [The method] allows a greater scope of research throughout the } \\
& \text { semester. It enables us to value other teams' understandings and } \\
& \text { contributions, to exchange ideas between the team members and to } \\
& \text { reach consensus. [Because there is] the need to do research on a } \\
& \text { weekly basis, [it compels us] to think up effective methods of doing } \\
& \text { research, writing reports, communicating with other team members... }
\end{aligned}
$$

Despite the fact that PBL was evaluated as satisfactory by the majority of the students from both cohorts, some of them saw some disadvantages in this instructional approach. One of the shortcomings they cited was its overdependence on the students' self-directedness and motivation: "It depends too much on the students being motivated to search for knowledge" (UGO3), and "One disadvantage is that in order to work well all students must be willing to participate" (G13). Indeed, student participation is a sine qua non of PBL, and differs from conventional education where students can, to some extent, be aloof or absent in some classes and catch up later during the course.

This constant pressure for participation may also have been perceived as taxing by some students as illustrated in "[The method] forces students to participate and this may sometimes inhibit them because of their [more 
reserved] personalities" (GO2). Evidently, the students' personalities, learning styles and comfort level should always be taken into account when adopting an active-learning method such as PBL (Kaufmann \& Mann, 2001). However, students should be informed from the beginning that the PBL activities involving teamwork and presentations have not been devised solely to enhance learning, but also to prepare them for situations they are likely to encounter in their future professional practice. Although deemed as of lesser importance by some academics, these skills may be vital to engineers, as many reach managerial positions ten years after graduation (Hadgraft, 1993).

The students also expressed the concern that PBL increased the workload and was more time-consuming than conventional methods. This may be especially true in this implementation context, in which the steady workload required by the approach may have conflicted with the demands of their other subjects and personal commitments: "I think the method is interesting, but the constant work gets out of hand, because the team members have other subjects to study" (UG20), and "It is a motivating method, but it requires much more commitment and responsibility from the students" (G06).

While it was observed that the method did increase the students' workload and study time, this concern has to be analyzed vis-à-vis the educational contexts under consideration. The UG students had a full timetable (a common fact in engineering courses in Brazil), and most of the PG students held jobs and/or lived in other places. Also, the students' perception of greater workload and time demands may be more related to the fact that they had to put in work on a weekly basis than to the amount of work itself. Indeed, it was generally observed that the approach challenged the students' capacity to manage their time and other constraints (e.g. some $G$ teams held on-line meetings). In short, in this implementation the students had to manage their study time differently and perhaps more efficiently, and some students may not have been completely successful in adjusting to this change.

Another negative assessment was that the content was superficially learned under PBL: "The method is good but the exploration of the topics is superficial" (UGO2), "I feel I have learned a lot of things, but I don't have a clear and organized picture of what I have learned" (UG10) and "There is just one thing I would like to remark: the students with no previous knowledge in Administration may not have been able to adequately construct the building that houses the administration theories" (G06). First of all, it must be explained that the subject was general in nature and covered a wide range of theories, which made it impracticable to explore each one of them in depth irrespective of the method of instruction used. Secondly, it should be said that the capacity of PBL to promote content acquisition is still a source of debate, as some studies show a small advantage in favor of more conventional methods. However, some authors, such as Stinson \& Milter (1996), challenge this difference even though it is small, because they believe it is based on results of standardized objective tests, which only measure the students' capacity to memorize non-contextualized concepts, and also because they may be indicative of weaknesses in the implementations rather than in $\mathrm{PBL}$ itself. At any rate, contrary to G06's perception, a recent meta-analysis on 
PBL research suggests that it favors the development of a better structured knowledge base in comparison to lecture-based methods (Dochy et al., 2003).

The aforementioned time and workload issue must also have prevented the students, particularly the UG ones, from looking at the topics in detail. Given that students using PBL are the ones primarily responsible for the topic investigation, insufficient time may have resulted in superficiality, thus inadequate knowledge acquisition. Also, the comments coming especially from older $G$ students, who were themselves teachers, on the need for previous knowledge - which is contrary to PBL principles - may be attributed to their schooling in conventional environments (where teaching is usually equated to learning), personal beliefs about what a good class and a good teacher should be and deficient pedagogical training. The combination of these factors may have helped to forge their idea that lecturing is the most effective way of teaching theory at all times.

Despite these negative reactions the majority of the students from both cohorts stated that the method favored the acquisition of knowledge, as illustrated by the following excerpts: "I think so [the method promoted content acquisition], because I consider what I have learned to be of great benefit to my career, and even to my life!" (UG23) and "Yes, it did. I began to see the function of Administration in other ways, with special emphasis on the consequences of a decision made without taking into account all the factors involved in the process" (G03).

On the whole, the students also acknowledged the development of some of the skills attributed to PBL (Albanese \& Mitchell, 1993), such as problemsolving skills: "Rather than just learning the theory [...] we learned where to look for solutions to the problems, how to analyze the solutions and appraise them" (UG21) and "The students developed a stronger attitude towards investigating the topics in books, on the Internet... always in search of a better solution to the problems" (UGO1); teamwork skills: "Knowledge was acquired through the activities, which also contributed to the development of our ability to work in teams" (G17); oral and written communication skills: "In the first problems [weeks] we all seemed to be lost [...], but in the last classes it was easy to see the students' progress. Owing to their accumulated experience they worked better, produced better reports and felt more confident to present them" (UG17); self-directed learning: "It was interesting to be able to develop different skills [...] and learning how to learn" (PGO4).

Regarding attitudes, the students from both cohorts either were vaguer or did not differentiate them from the skills, which may reflect the fact that these attributes are seldom singled out or assessed in conventional syllabuses. Besides, as indicated by some students' comments, some unwanted attitudes took place, such as corporatism and 'free rides' (which led the teacher to rearrange the teams at mid-semester): "I was honest and considered the team as an organization [...]. However, many students were just concerned about the grades, even compromising to give E's [Excellent] to all team members, regardless of their performance in the process that week" (G15). This excerpt illustrates how difficult it is to promote attitudes and to change study strategies forged in an educational culture based on getting grades to pass. 
However, in spite of that, other students did report the promotion of some desirable attitudes: "[The students] developed the ability to work in teams, [...] respecting other people's opinions" (UGO1) and "[The students developed some] attitudes concerning the team and the class as a whole, such as collaboration, time planning, complying with deadlines, respecting other students' difficulties" (G12) etc.

The teacher's views about the method In general, the teacher's views were in agreement with that of the students. Besides affirming that PBL made the class more interesting and dynamic, he stated that it might have favored the students' acquisition of knowledge and development of skills and attitudes. He also believed the method was more efficient in promoting self-directed learning and critical thinking as compared to more conventional ones:

My impression is that the method does bring about research...I mean, it is good because it is only through research and reflection on what we've found that we can learn. That is what we do as [academic] researchers; we are always trying to solve a problem [...]. It is the opposite of conventional teaching, which does not provoke anything...

Nevertheless, the teacher also felt that PBL demanded greater maturity a more intrinsic motivation from the students in order to function properly:

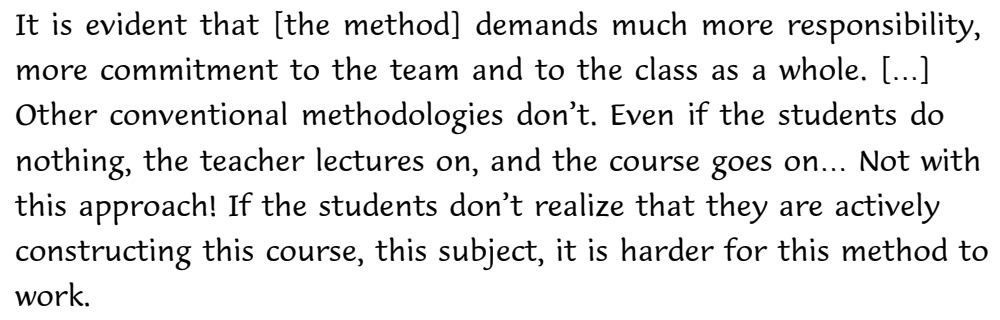

On the other hand, whereas it is true that the method demanded more active participation from the students, it did not reduce the participation of the teacher in and outside the classroom. On the contrary, it was observed that the role change resulted in more work for the teacher in both instances; however, the work was different from the kind of work he used to do. Even though the method may have lightened his role as the provider of knowledge, it seems to have increased his responsibility in the management of the instructional process. This means that the method may have been more timeconsuming to him as much as it was to the students, in comparison to his former way of teaching.

Indeed, it was observed that the instructional approach increased the workload and time expenditure for the teacher, in the same way it did for the students. As it distributed the work evenly throughout the semester, the method also required that the teacher control his time more carefully. It made it more difficult for him to postpone work (e.g. marking the reports) and miss 
a class due to other academic commitments (e.g. conferences) or personal matters (e.g. sickness).

Moreover, the teacher reported that he had provided more feedback to the students and had done more assessment (of students' self-, peer and process evaluation forms, presentations and reports) than he would have done in a more conventional method of instruction, and this is per se a time consuming activity:

I don't know. I haven't paid attention to time... I think I took me more than one hour to handle all the [preliminary and final] reports [of the week before]... to sort them out according to the teams, to give them written feedback... I think that's time-consuming, I mean, giving them written feedback. But this is so important! I even heard some students whisper [...]: 'Oh, he [the teacher] gives feedback!

Furthermore, as the implementation allowed for on-going process evaluation, this meant that the classes (problem-solving cycles and problems) could not be entirely prepared in advance. There were always changes and improvements to be made in the format of the reports, problems and presentations in response to the students' evaluations as well as the teacher's classroom observations in the previous week. This differed from the teacher's former class planning mode, which was mostly done during the students' vacations. Thus, besides increasing the teacher's time expenditure, the method also seems to have restrained the management of his time - an important point of consideration when implementing PBL in a research university such as the one in question.

In addition to increasing the time devoted to the subject, the teacher also felt that PBL would not suit beginning teachers or teachers with limited knowledge of the content under consideration. In his opinion PBL worked better with expert teachers. This is the reason that despite being an accomplished academic, he chose to implement the method in just one of his subjects, i.e., Administration Theory, which he had been teaching at the university for over twenty years.

$\mathrm{He}$ basically perceived PBL as increasing the degree of unpredictability in the classroom as compared to conventional teaching, and this unpredictability could sometimes challenge the teacher's expertise in unwanted ways. For example, when the students come up with issues beyond or outside the teacher's knowledge of the subject matter:

I think that for the teachers that [lecturing] system is easier, because they can prepare their classes as they please and everything is extremely predictable. The students are just there receiving information without questioning it. [Whereas in PBL] we could say that there is a degree of unpredictability with regard to the teacher's class planning. [...] The teacher instigates the students with a problem, and he or she does not have precise control of what is going to happen in response.

Although this excerpt is focused more on the teacher's feelings before and in 
the beginning of the implementation, it is important in that it illustrates how conventional faculty members may view instructional innovations such as PBL.

As a possible outcome of the unpredictability of teaching using this method, the teacher was concerned about how the students would react to the eventual lack of knowledge on his part:

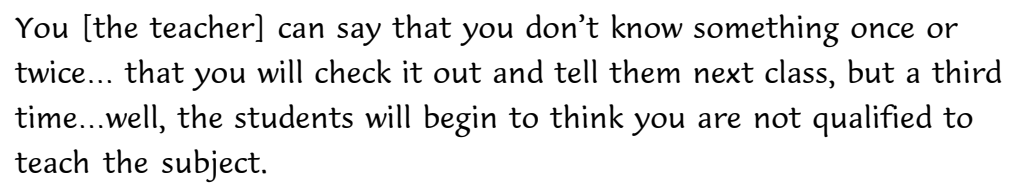

This uneasiness may have its origin in the culturally shared archetype of a good teacher, i.e., that of the expert and knowledge imparter, as well as in the way he developed his teaching practice: "from scrap". Without having had any pedagogical training (a common fact among Brazilian engineering educators), he constructed his practice in a long, solitary process of trial and error, based on his experiences as a student in more conventional educational environments, and by emulating the practice of his teachers. This may be one of the reasons why so many engineering teachers resist alternative methods: their practice mode (which worked for them after all), however imperfect, is all they know, and because they have expended time and effort in its construction, they are not willing to give it up easily.

This unpredictability may also be the source of some faculty's fear of losing control over the course content, especially those used to a more linear and sequential teaching mode. In the beginning the teacher was noticeably concerned that the students would come up with solutions to the same problem grounded on too disparate administration topics, such as leadership, strategy, structure etc. He believed that they would not be able to learn anything in depth and that he would be unable to produce a consistent final synthesis of the theory generated by the problem. Although this diversity of visions may be construed as positive (as most real-life problems have multiple causes), it can also make it more difficult to examine a topic in detail in a classroom context. At any rate, this concern proved to be unfounded as the problems themselves succeeded in directing at least some of the teams to the topic in question.

In addition, the occurrence of less suitable solutions - related to other topics - was also beneficial to the teacher, as these secondary topics assisted him in the construction of his synthesis (by serving as counter-arguments) and in understanding his students' reasoning through the problem-solving process:

Engineering students are so positivist! They always think that an organizational problem is caused by people, employees...for them it is always a Human Relations problem ... they never blame it on the organization structure, process...

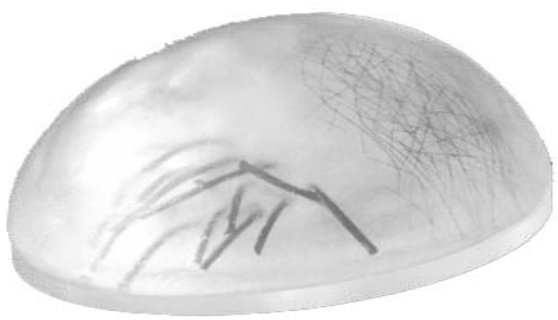




\section{Conclusion}

Despite the aforementioned concerns expressed by the teacher and the students, the results of this study explicitly favor the adoption of PBL as a viable instructional method for this context. Nevertheless, the main issues that were brought up by these actors need to be carefully addressed. In particular, time expenditure has to be closely monitored so as not to interfere with the students' and the teacher's remaining academic and/or personal commitments. It is clear that time pressures will lead to the students' lack of depth in research and cursory performance of activities that could otherwise enhance their professional training, promote life-long learning, and prepare them for their future practice and the professional world.

On the other hand, excessive work also affects teachers in the sense that it deprives them of the time they need to reflect on and improve their practice, which seems to have been encouraged by this PBL implementation. It was observed that the teacher constantly assessed the institutional culture, his values and beliefs, his practice and the students' reasoning through the problem-solving process. Therefore, as long as there is sufficient time, the sum of these reflections may lead teachers to become better professionals, a desired outcome in the Brazilian engineering education context, where so many teachers lack formal pedagogical training.

Although it should not be expected that this method of instruction is capable, by itself, of making up for this deficiency, the findings of this study suggest that it can become a powerful aid in this quest. Likewise, the collaborative design adopted in this research also played an important part in

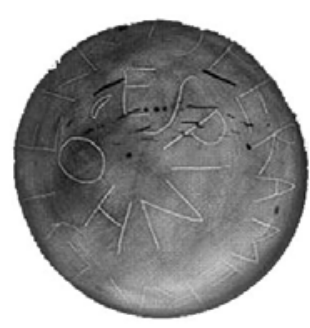
this process by providing opportunities for the exchange of ideas between the researchers and the teacher and promoting the dialogue between teachinglearning theory and practice in the teacher's workplace.

\section{References}

ALBANESE, M. A.; MITCHELL, S. Problem-based learning: a review of literature on its outcomes and implementation issues. Acad. Med., v.68, n.1, p.52-81, 1993.

BARROWS, H. S. Problem-based learning (PBL). Available from: <http://www.pbli.org/pbl/>. Accessed: June 16, 2001.

COLE, A. L.; KNOWLES, J. G. Teacher development partnership research: a focus on methods and issues. Am. Educ. Res. J., v.30, n.3, p.473-95, 1993.

DENZIN, N. K.; LINCOLN, Y. S. Entering the field of qualitative research. In: DENZIN, N. K.; LINCOLN, Y. S. (Eds.) Handbook of qualitative research. Thousand Oaks: Sage Publications, 1994. p.1-17.

DOCHY, F.; SEGERS, M.; VAN DEN BOSSCHE, P.; GIJBELS, D. Effects of problem-based learning: a metaanalysis. Learning and Instruction, v.3, p.533-68, 2003.

ENGEL, C. E. Not just a method but a way of learning. In: BOUD, D.; FELETTI, G. (Eds.) The challenge of problem-based learning. London: Kogan Page, 1998. p.17-27.

HADGRAFT, R. A problem-based approach to civil engineering education. In: RYAN, G. (Ed.) Research and development in problem-based learning. Sydney: University of Sydney-MacArthur Press, 1993. p.29-39.

KAUFMANN, D. M.; MANN, K. V. I don't want to be a groupie. In: SCHWARTZ, P.; MENNIN, S.; WEBB, G. 
RIBEIRO, L. R.; MIZUKAMI, M. G.

(Eds.) Problem-based learning: case studies, experience and practice. London: Kogan Page, 2001. p.142-50.

NING, C. C. Undergraduate academic programme: planning, development, implementation and evaluation. Int. J. Engng. Educ., v.11, n.3, p.175-84, 1995.

SAVIN-BADEN, M. Problem-based learning in higher education: untold stories. Buckingham: Open University Press, 2000.

STEPIEN, W.; GALLAGHER, S. Problem-based learning: as authentic as it gets. In: FOGARTY, R. (Ed.) Problem-based learning: a collection of articles. Arlington Heights: SkyLight, 1998. p.43-9.

STINSON, J. E.; MILTER, R. G. Problem-based learning in business education: curriculum design and implementation issues. In: WILKERSON, L.; GIJSELAERS, W. H. (Eds.) Bringing problem-based learning to higher education: theory and practice. San Francisco: Jossey-Bass, 1996. p.33-42.

TYNÄLÄ, P. Towards expert knowledge? A comparison between a constructivist and a traditional learning environment in the university. Int. J. Educ. Res., v.31, p.357-442, 1999.

WILKERSON, L.; GIJSELAERS, W. H. Bringing problem-based Learning to higher education: theory and practice. San Francisco: Jossey-Bass, 1996.

WOODS, D. R. Problem-based learning for large classes in chemical engineering. In: WILKERSON, L.; GIJSELAERS W. H. (Eds.) Bringing problem-based learning to higher education: theory and practice. San Francisco: Jossey-Bass, 1996. p.91-9.

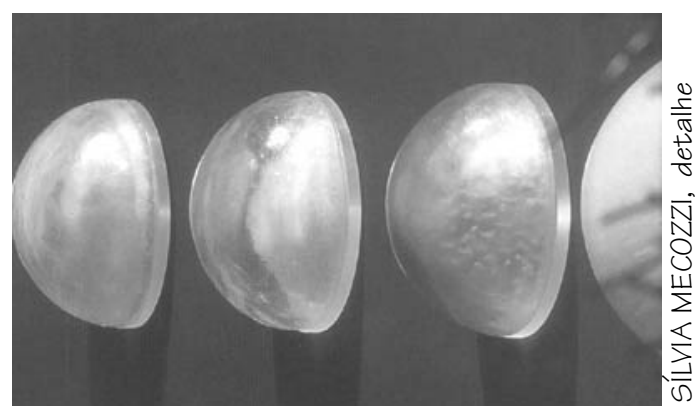

RIBEIRO, L. R. C.; MIZUKAMI, M. G. Un experimento con el PBL en la educación superior evaluado por el profesor y los estudiantes. Interface - Comunic., Saúde, Educ., v.9, n.17, p.357-68, mar/ago 2005.

El Aprendizaje Basado en Problemas (Problem Based Learning o PBL) ha sido reconocido mundialmente como un abordaje instruccional capaz de promover en los alumnos la adquisición de conocimientos, al mismo tiempo que los ayuda a desarrollar habilidades y aptitudes profesionales deseables. Contrariamente a los métodos convencionales que recurren a problemas de aplicación después de haber impartido la teoría, el PBL usa un problema para iniciar, enfocar y motivar el aprendizaje de nuevos conceptos. Este texto presenta y discute los puntos de vista de los estudiantes y del profesor respecto a la implementación del PBL en la asignatura Teoría General de la Administración, del currículo de ingeniería, en una universidad publica de Brasil. Los datos fueron recolectados por medio de entrevistas no estructuradas, observación participante y un cuestionario respondido por los estudiantes al final del semestre. Los resultados muestran que, a pesar de aumentar la carga de trabajo del profesor y de los estudiantes, todos clasificaron al PBL positivamente por ser más motivador y dinámico.

PALABRAS CLAVE: aprendizaje basado en problemas; educación superior; metodología de enseñanza. 